\title{
Sexuality of adolescents living with HIV/AIDS: sources of information defining learning
}

\author{
Sexualidade de adolescentes que vivem com HIV/aids: fontes de informação delimitando aprendizados \\ Sexualidad de adolescentes que viven con VIH/sida: fuentes de información delimitando aprendizajes
}

Graciela Dutra Sehnem Eva Neri Rubim Pedro ${ }^{2}$ Lúcia Beatriz Ressel ${ }^{3}$ Maria Eduarda Deitos Vasquez ${ }^{1}$

1. Universidade Federal do Pampa. Uruguaiana, RS, Brazil

2. Universidade Federal do Rio Grande do Sul. Porto Alegre, RS, Brazil

3. Universidade Federal de Santa Maria. Santa Maria, RS, Brazil
Corresponding author: Graciela Dutra Sehnem E-mail: graci_dutra@yahoo.com.br

Submitted on $04 / 28 / 2017$ Accepted on 11/06/2017.

DOI: 10.1590/2177-9465-EAN-2017-0120

\section{Abstract}

Objective: To know the sources of information of adolescents living with HIV/AIDS that define learning about sexuality. Methods A qualitative study was performed in a Specialized Care Service of a city in the state of Rio Grande do Sul, Southern Brazil, with 15 adolescents living with HIV/AIDS. A semi-structured interview and thematic analysis were used. Results: Adolescents have built up their knowledge about sexuality, especially through relationships with friends and older family members, or through access to media sources. Schools and health services were spaces for sharing information about biological aspects of sexuality. Conclusion: Nurses need to address adolescent sexuality beyond the biological dimension and support it through critical and dialogical health education.

Keywords: Sexuality; Adolescent; Acquired Immunodeficiency Syndrome; Adolescent Health; Nursing

\section{REsUMO}

Objetivo: Conhecer as fontes de informação de adolescentes que vivem com HIV/aids que delimitam aprendizados acerca da sexualidade Método: Pesquisa qualitativa realizada em um Serviço de Atendimento Especializado, de um município do interior do Rio Grande do Sul, com 15 adolescentes que vivem com HIV/aids. Utilizaram-se a entrevista semiestruturada e a análise temática. Resultados: Os adolescentes construíram seus conhecimentos acerca da sexualidade, principalmente, a partir das relações com os amigos, com algum membro da família mais experiente que eles, ou pelo acesso a fontes midiáticas. A escola e o serviço de saúde constituíram espaços de socialização de informações relativas aos aspectos biológicos da sexualidade. Emergiram relatos de despreparo e desconhecimentos para a sua experimentação. Conclusão: Os enfermeiros precisam abordar a sexualidade dos adolescentes para além da dimensão biológica e respaldá-la em uma educação em saúde crítica e dialógica.

Palavras-chave: Sexualidade; Adolescência; Síndrome da imunodeficiência adquirida; Saúde do Adolescente; Enfermagem.

\section{Resumen}

Objetivo: Conocer las fuentes de información de los adolescentes que viven con $\mathrm{VIH} /$ sida que delimitan aprendizajes sobre sexualidad. Métodos: Investigación cualitativa realizada en un Servicio de Atención Especializada de una ciudad del interior del Rio Grande do Sul, con 15 adolescentes viviendo con VIH / sida. Se utilizó entrevista semi-estructurada y análisis temático. Resultados: Los adolescentes han construido sus conocimientos sobre la sexualidad a través de las relaciones con los amigos con un miembro de la familia mayor que ellos, o el acceso a los medios de comunicación. La escuela y el servicio de salud fueron espacios para la socialización de informaciones relativas a los aspectos biológicos de la sexualidad. Conclusión: Las enfermeras necesitan abordar la sexualidad de los adolescentes más allá de la dimensión biológica y apoyarla en la educación en salud crítica y dialógica.

Palabras clave: Sexualidad; Adolescente; Síndrome de Inmunodeficiencia Adquirida; Salud del Adolescente; Enfermería 


\section{INTRODUCTION}

In the Brazilian context, there has been a continuous increase in HIV infection (acquired immunodeficiency virus)/ AIDS (acquired immunodeficiency syndrome) in the population. ${ }^{1}$ In 2016, a total of 19,998 cases of adolescents living with HIV/ AIDS aged from ten to 19 years were reported. ${ }^{2}$ Under such chronic condition, adolescents are faced with complex questions in their routine, such as adherence to antiretroviral therapy, family relationships, silence and the revelation of diagnosis, being an orphan, adolescence in institutions like adolescent support centers, and experiences with sexuality, among others. ${ }^{3,4}$

Regarding sexuality, several implications associated with seropositivity are experienced by adolescents living with HIV/ AIDS, especially those related to the fear of revealing the diagnosis to their partner, the stigma and prejudice expressed by society, reproductive questions, changes in body image, the desire to have a family, and future plans. ${ }^{4-6}$

At times, this dimension can be limited, so that the risks to sexual life can be controlled. The aspirations and needs of adolescents living with HIV/AIDS tend to be restricted by themselves or by individuals who live with them, compared to those of other adolescents at the same age. ${ }^{4}$ Even under social conditions that create a high level of vulnerability, to some extent, adolescents will always be active in their sexuality. Thus, it is useless to seek mechanisms to control it. ${ }^{7}$

Sexuality is one of the main domains that encourage adolescents to create a sphere of individual autonomy. This learning includes a process of personal experimentation and impregnation with the culture of the group. ${ }^{4,8}$ The experiences of adolescents associated with sexuality are influenced by the environment in which they live and share their life with their family, friends, media, school, and all that surrounds them and matters in a positive or negative way. ${ }^{8}$

At this stage, they become interested in obtaining information and seeking answers to their questions through different sources, especially with regard to their sexuality. ${ }^{3,9}$ Access to qualified information on this theme is one of adolescents' rights, which must be met in the context of schools and health services that care for this population. ${ }^{4,8}$

Aiming to identify the scientific production on the access to and sources of information on sexuality among adolescents living with HIV/AIDS, a search was conducted in the Brazilian and international literature through the following databases: Literatura Latino-Americana e do Caribe em Ciências da Saúde (LILACS - Latin American and Caribbean Literature on Health Sciences) and Medical Literature Analysis and Retrieval System Online (MEDLINE). The available production was mainly aimed at adolescents who did not have such chronic condition and only two international studies dealt with this theme and target population. Such production dealt with the implications of access to information on sexual and reproductive health in the behavior of adolescents living with HIV/AIDS and the use of mobile applications to share information on this theme among them.
In light of this, in Brazil, studies on access to and sources of information on the sexuality of adolescents living with HIV/AIDS are incipient in the area of Nursing and Health Sciences, thus revealing a gap in scientific production and justifying the need for greater investments in research on this theme.

In this sense, the present study raised the following research question: What are the sources of information that define learning about the sexuality of adolescents living with HIV/AIDS? To answer this question, this study aimed to identify the sources of information of adolescents living with HIV/AIDS that define their learning about sexuality.

\section{METHODS}

An exploratory and descriptive study with a qualitative approach was performed, ${ }^{10}$ resulting from the doctoral thesis entitled "Sexualidade do adolescente que vive com HIV/aids: contribuições para a visibilidade da educação em saúde" (Sexuality of adolescents living with HIV/AIDS: contributions to the visibility of health education). The scientific production resulting from this thesis should be emphasized: "A saúde no adolescer com HIV/aids: caminhos para uma agenda pós-2015" (The health of adolescents with HIV/AIDS: paths for a post-2015 agenda). ${ }^{4}$

The study location was the Serviço de Assistência Especializada (SAE - Specialized Healthcare Service) of a city in the state of Rio Grande do Sul, Southern Brazil. Participants included 15 adolescents living with HIV/AIDS who were being followed in the SAE. This number was based on the data saturation criterion. ${ }^{10}$

The inclusion criteria were as follows: to be living with HIV/ AIDS regardless of how one was infected with the virus; to be using or not using antiretrovirals; to be aged between ten and 19 years, according to the Ministry of Health's definition of adolescence ${ }^{11}$; and to be followed in the SAE. Individuals who were not aware of their diagnosis were excluded from this study. This information was obtained from family members or the legal guardians of adolescents and health service professionals.

Initially, a search was performed through SAE medical records to select participants. In the first stage of this study, health professionals both acted as mediators for the selection of adolescents, indicating the names of possible participants who met the study requirements, and introduced them to the researcher.

As a strategy to approach adolescents and enable them to become familiarized with researchers, interactive educational games and a cosmetic make-up workshop were used. These activities took place on a weekly basis in a SAE room, on dates previously selected for them, in the mornings and afternoons. These playful activities, apart from being a source of pleasure and discovery for participants, also contributed to the formation of strong bonds.

Data were collected through semi-structured interviews. The following interview questions stood out: Do you talk to anyone about your sexuality? Who do you talk to? What do you 
talk about? Does your family talk to you about this? Do you talk about your sexuality with any health professionals from the SAE?

Prior to the interview, adolescents aged more than 18 years signed an Informed Consent Form (ICF), whereas minors signed an Agreement Form and their parents or legal guardians signed the ICF. Data were collected in the SAE (13 participants) and at home (two participants), according to participants' preference. Anonymity was guaranteed in both locations. Interviews were recorded on audio in a digital recorder and fully transcribed.

Data analysis was based on Minayo's operative proposal, characterized by two operational levels ${ }^{10}$. The first level refers to the exploratory stage. Next, the second operational moment, known as interpretative, occurred into the following two stages: data ordering and classification.

The present study followed the principles of Resolution 466 issued by the Ministry of Health's National Health Council in 2012 and it was approved by the Research Ethics Committee under number 295045. Aiming to guarantee participants' anonymity, adolescents were identified by the letter $A$, followed by a number: A1, A2, A2 (...) A15.

\section{RESULTS AND DISCUSSION}

Regarding the characterization of study participants, ten out of the 15 adolescents were females and five were males. All of them had been infected through vertical HIV transmission and used antiretroviral drugs. In terms of age, participants were aged between 11 and 19 years. Additionally, with regard to level of education, 12 adolescents had an incomplete primary education level and, of these, two were not attending school during data collection; and three had an incomplete secondary school level.

Adolescents originated from poorer families with an income of up to one minimum age per month. Regarding family structure, both parents had died in the case of six adolescents; the mother had died in the case of six adolescents; the father had died in the case of two adolescents; and one adolescent had no contact with his parents, so he could not provide such information. A total of six adolescents lived with their grandparents, especially their maternal grandparents; two, with their biological mother; three, with their adoptive families; one, in an adolescent support center; two, with their partners; and only one, with both biological parents. It should be emphasized that, of all 15 adolescents participating in this study, four had a father or mother in prison and six lived with parents or family members who used alcohol and/or other drugs.

Data analysis led to two thematic categories, described as follows.

\section{We learn together: peers, family and media as spaces for sharing information}

Regarding conversations with individuals in the same age group, the group of peers is an important space for information on sexuality issues. These moments are an opportunity to learn from one another and, at times, show their experiences about sexuality issues.
I like to talk with my friend because we're the same age, he's going through adolescence like me. We understand each other, we learn together. It's good to grow up with him. He tells me that when I do it, it'll have to be with a condom. When I experience this, I'll already know what it's like. (A7)

It's better to talk to my friends, because we do the same things. I like to chat with them to get answers for my questions, they say that when we do it, we have to use a condom, they explain how to put it on. [...] About the pill [contraceptive], they say I should take it, what it prevents, that I got to see a doctor to find out what kind I should take. At times, I'm the one who teaches them. (A1)

Adolescents' sharing of sexuality mainly occurs among peers, when conversations about this theme stand out, whether because it is easier to talk to friends due to their similar age range and non-judgmental nature or because dialogue with parents can be hindered by the difference in generation.

Friends become role models for adolescents to validate knowledge and strongly influence their behavior. ${ }^{4,8}$ Several studies have shown that friends were pointed out by adolescents as the group with whom they feel the most comfortable to talk about and ask questions about sexuality. ${ }^{4,12-15}$

Additionally, adolescents also internalize information on sexuality by observing the experiences of their peers. They observed these experiences in the family and school contexts, especially with regard to questions such as pregnancy or sexually transmitted diseases, which may serve as examples influencing their choices.

My sister got pregnant at 13, then she tried to have an abortion. She took so much medicine on her own that she ended up miscarrying it. Then, she got pregnant again at 14. I don't want this life for myself. I'm afraid of getting pregnant or catching a disease, I want to enjoy my life. (A3)

To have a child is such a burden. I know girls at school who are 12 and 13 and got pregnant, but the boys didn't take responsibility. (A6)

Situations that generate information from experiences with friends are characterized as warnings and they have special significance to learn about sexuality, as these individuals are meaningful for adolescents. In this sense, a study performed in Portugal with 4,877 adolescent students showed that peers have a direct influence on the risk behavior of such students, which can be positive or negative as it is associated with the type of conduct adopted by their friends. Alcohol and drug use, involvement with violence and unprotected sexual practices stand out as negative influences. In contrast, health care and well-being and feelings towards school are some of the positive influences. ${ }^{16}$

Thus, the need to improve education among peers was emphasized, as it is a teaching and learning process where adolescents act as facilitators of actions and activities with and 
for other adolescents from the same group. ${ }^{11}$ In light of this, the types of communication among the different participants involved in the production of information for adolescents must be developed and recreated, apart from renewing forms of expression and diversifying and connecting social networks, improving their exchanges. ${ }^{4}$

In contrast, as far as family is concerned, the dialogue about sexuality is still taboo, leading to silence and secrecy. Adolescents reported not being able to talk to their parents or grandparents about this topic, due to both the lack of openness for discussion and the fear of adults judging them for their experiences.

I don't talk about this with my grandma. She never said a word. She's not open to talk about this and I feel embarrassed to bring it up. (A5)

My mom doesn't talk to me about these things, because she thinks it's silly. She never gave me advice, she never said, "When you start dating, you got to do this or that, when it's time for sex, you got to use a condom.". (A13)

My mom is not open to talk about this. I've tried before, one day I almost told her that I'd been with a guy, but she looked angry and so I didn't tell her. I'm afraid she may beat me. (A11)

I don't talk to my dad about these things, he doesn't talk much, he's a bit rude. He doesn't understand me. I've never asked him anything. (A14)

Parents and grandparents feel frequently intimidated when touching on the topic of sexuality with their children or grandchildren, especially when their sexual education was permeated by repression ${ }^{4}$. This difficulty encountered when dealing with adolescent sexuality in the family causes the educational role to be transferred to others and it reproduces disciplinary ways of control, which could maintain this cycle for many generations. However, when sexuality is not discussed by the family, the experiences in this dimension go against parents and grandparents, becoming difficult and conflicting.

To approach this theme with children is not an easy task for the majority of parents, as this often brings up repressed aspects of their own sexuality. ${ }^{17}$ Studies have revealed that parents find it difficult to talk about sexuality with their children, which may be justified by the fact that this involves myths, taboos, prohibitions and silences..$^{14,18}$

Due to this repression in the learning process about sexuality, feelings such as shame to deal with this theme emerge and greatly inhibit the flow of conversation carried out by families. ${ }^{13,18} \mathrm{Apart}$ from this question, some parents postpone conversations about sexuality, based on the belief that this will encourage their children to become sexually active ${ }^{4}$.

Fear of encouraging children to begin sexual activity also stood out in a recent study performed with mothers of adolescent girls in Australia. ${ }^{19}$ In the present study, some of the participants reported that they believed adolescents approaching themes related to sexual health could be a facilitator of experimentation of risk sexual behavior. ${ }^{19}$

Adolescents mentioned some family members such as uncles/aunts and siblings as sources to answer questions about sexuality. According to adolescents, conversation flows better with these family members, compared to parents or grandparents, due to the similar age and because they have already had sexual experiences, giving them confidence to choose such individuals as relevant sources of information.

I talk to my aunts. I like talking to them, because it seems they're just like me. I feel more confident talking to them. They always advise me, they talk about everything. [...] They say that, when I have sex, I must be safe. (A12)

I talk to my older sister. I trust her and she understands me. She knows everything, she really does. She gives me advice and tells me to be careful when having sex and to use a condom. She asks me to take the medication and care for her [girlfriend]. She says I cannot drink because of this this medication. I ask her what I can and cannot do. (A14)

I talk to my uncle. He understands me. He listens to me and tells me things. [...] He tells me to take care of myself and if I'm doing something wrong, he advises me. (A10)

The family role can be identified, especially that of siblings and uncles/aunts, as a safe source of information for adolescents, who preferred to be advised by older individuals who had already had sexual experiences. ${ }^{4}$ This is in agreement with other studies that included a search for family members who were older, such as uncles and aunts, brothers and sisters, and cousins, as sources of information to talk and to and answer questions about sexuality. ${ }^{20}$

In the relationships established between adolescents and parents or grandparents, what was forbidden became at times more flexible, even being allowed to some extent, although simply to talk about sexually transmitted diseases, unwanted pregnancies, and ways to prevent one's partner to be infected with HIV.

My mother is always telling me: "Never hook up with a boy without a condom!". And she tells me that I should use a condom and take care of myself not to get pregnant. (A3)

My grandma talks about pregnancy and says it's too early for this. She tells me to take care of myself and use a condom. (A2)

My mother keeps telling me to use a condom and that I should tell my boyfriend that I have HIV when we have sex for the first time. She said I should take care of myself not to be pregnant, because I'm too young for this. (A9) 
In the family conversation, sexuality was associated with risk. Parents' and grandparents' anxiety to protect adolescents from the possible risks of unprotected sexual intercourse and to protect their partners from HIV infection. The family approach to sexuality is restricted to the sexual act and is mainly aimed at preventive aspects, which could be observed in the reports that emphasize the use of contraceptive methods. ${ }^{4}$

This limited approach to sexuality in the family environment, restricting it to a preventive and biological condition, has been indicated in the literature by different authors. ${ }^{13,14,21}$ This type of dialogue, when parents use certain technical-scientific knowledge in their conversations about sexuality with their adolescent sons/ daughters, is known as medicalization of sexuality, as the theme is frequently associated with negative consequences such as diseases and unwanted pregnancy. ${ }^{13,22}$

Some adolescent orphans reported that they missed their mother or father to comfort them and give them advice on questions associated with experiences with sexuality.

I miss my mom to talk about this stuff, she'd understand me. She passed away when I was five. (A1)

I miss talking to my mom, she'd help me with everything, answer my questions. She passed when I was ten. (A15)

I wish my dad was alive to talk to him about this. He was always there for me. It'd be great. (A10)

Being an orphan as a result of AIDS can have an impact on the way adolescents experience sexuality, considering the fact that the resources they have to cope with different situations created by these experiences tend to become more restrictive with the absence of their parents, key role models for such information. In these reports, the weight of missing one's deceased parents and suffering from their absence adds to the uncertainties about and anguish for sexuality.

A study performed with Colombian adolescents found that they view their parents to be the best source of information on sexuality. ${ }^{23}$ Communication within the family about this theme is an interesting strategy to experience sexuality in a more peaceful way. However, parents need to develop this space that encourages discussion. ${ }^{23}$

Moreover, with regard to the lack of information resulting from the orphan condition, one of the adolescents who experienced a period of institutionalization in an adolescent support center.

About my period, I talked to a woman there [adolescent support center], because I was there when my period came. I had nobody else to talk to. (A4)

It is possible to infer the absence of not only a family role model for such conversation, but also other spaces that have avoided commitment to this debate and reflection. We believe a relevant question can be raised here: How have the school and health service enabled institutionalized adolescents living with
HIV/AIDS to express themselves about their questions, especially those regarding sexuality?

In addition to the search for information on learning about sexuality with friends and family members, adolescents also took advantage of media sources.

I get answers to my questions when I read magazines and watch TV. I've read things about condoms in these magazines. (A15)

I saw some stuff on TV and I'd pay attention, I'd try to understand and get answers to my questions. I've seen some booklets at the clinic. (A10)

I saw a poster at the entrance to the clinic that read "STD" and I didn't know what that was. Sometimes, I read science books because they talk about HIV. (A3)

On the one hand, the role that the media has played in the lives of adolescents is undeniable, as it has increasingly influenced their routine as a source of information. On the other hand, we should take into consideration the fact that all kinds of information on sexuality can be accessed, which may help them or make them even more confused depending on where such information is sought. It is known that some information included in the media is questionable or even misleading.

Additionally, technical information that does not approach the language of adolescents can lead to questions, as observed when the participant said "I saw a poster at the entrance to the clinic that read "STD" and I didn't know what that was.". Thus, adolescents may feel unsure as to how to deal with all this information in the context of experiences with sexuality, which does not imply an understanding of how to care for oneself.

An Iranian study performed with 915 adolescents aged 14 to 18 years showed that one out of every three adolescents prefer media-based sources of information such as books (39.6\%) and the Internet $(37.9 \%)$ to obtain information on sexuality. Regarding the Internet, it seems that this source was selected as it is associated with easy access, confidentiality and variety of information available. ${ }^{3}$

Adolescents' preference for media resources consequently suggests that health programs seeking to inform them through public policies need to develop informative materials aimed at this population, as this may be a relevant tool to achieve this. For this reason, these materials must use appropriate language and be based on their experiences, without a recommended lifestyle and behavior, as it is frequently found. ${ }^{4}$

\section{She only talked about sex, it was already boring: education and health as spaces of socialization of information about the biological aspects of sexuality}

Adolescents' reports confirmed that the reductionist view of sexuality in the school context persists and is reproduced by both teachers and health professionals, echoing as a risk factor involved with this experience. According to adolescents, 
information focused on the use of condoms and contraceptive pills and prevention of sexually transmitted diseases and pregnancy.

At school, there were talks on how to use a condom, we'd listen to lecturers. [...] A psychologist and a doctor went there. They brought a toy penis, a condom for men and one for women, and showed how to put them on. (A13)

Some people from the health clinic went to my school, they only talked about the use of condoms, how to put them on, and the pill [contraceptive]. They brought some books to show us the diseases. [...] About pregnancy, they said we have to be careful, because we can't have a child while we're teenagers. (A15)

The science teacher talks about sexually transmitted diseases and HIV and explains what the symptoms are. She tells us that we have to use condoms and know how to put them on. (A7)

With the discourse of sexual protection embedded in the school environment, it can be deduced that this information, depending on the way it is approached by adolescents, can become a complicating factor as they seek to understand and explore their sexuality. In this sense, the educator (teacher/ health professional) needs to be aware of and prepared to bring up discussions and deal with values, taboos and prejudices. Nonetheless, they continue to have insufficient inner resources to handle these questions and end up approaching them from a biological perspective.

Aiming to overcome the perspective of control and to develop the discussions and practices about adolescent sexuality, schools need to deal with this theme, not only touching on anatomic-physiological aspects, but also and especially promoting self-reflection and knowledge about this theme. ${ }^{4,13,24}$ This is the only way to offer new possibilities to these individuals, beyond the repressive aspects experienced by them through their family, religion and society, thus offering new elements for the development of their own attitudes and actions. , $^{424}$

Likewise, in the SAE space, there is a trend towards sexuality themes being primarily discussed by professionals with a biological and reductionist approach, aimed at the perspective of risk. However, adolescents indicated that this approach does not meet their needs, expressed through their silence and discomfort at the moment of consultation with a professional and distancing from health services.

I only talked with this psychologist once. She asked me if I had already dated and had sex. I didn't like it, so I never went back. She didn't advise me. She only talked about sex, it was already boring. So I only listened to her. Today, I liked it better, because we talked about other things. (A3)

The first time I had a consultation, it was with the psychologist who works here [SAE], she asked my boyfriend and stepfather to come with me for the consultation. I felt bad, embarrassed. I didn't tell her anything, because my stepfather would tell everything to my mom. She picked up a kit to show me how to put on a condom, talked about the pill [contraceptive] as well. (A11)

I only talked to the nurse for one day. She just told me to take the medication not to infect the baby with HIV. (A2)

Ionly went to the doctor once, because I was embarrassed to talk with him about these things. He talked about my period. (A4)

It is possible to infer that there were few opportunities of sharing this theme with health professionals and adolescents considered it necessary for these professionals to incorporate a greater perspective of sexuality. Moreover, at the moment when the theme was approached, it was emphasized that taking one's individuality into consideration and respecting it is essential, otherwise there can be no dialogue and learning.

With regards to the work of professionals in health care, they must go beyond the biological model, which includes the physical and pathological aspects of sexuality exclusively. Thus, discussions and reflections on sexuality as a socially and culturally constructed dimension must be encouraged, aiming to be closer to adolescents and to achieve the promotion of comprehensive health. ${ }^{4}$ This could also deconstruct myths and taboos about sexuality that could have been developed in other spaces of sharing. Additionally, it could enable this theme to be dealt with on a level that goes beyond genitalia, encompassing life and history as a whole and an entire context of specific relationships. ${ }^{25}$

Adolescents reported the several questions they had about the experience of sexuality, including its many dimensions.

People had to talk to us about relationships here [SAE], if we have to mention the disease in the beginning, if we must say that we take medication. We should talk about condoms. I'd like to know if there is one for women. We should talk about the changes that are going to happen to our body, about the right time to have sex, if we really want to do it or if it's just to show our masculinity. I'm not sure if my child will have AIDS. I think there'll be more questions. About this, I know nothing so far. (A5)

We always have questions. They'd have to talk about what we're talking, which is what we like. It's important to talk to get answers to our questions. [...] About the use of condoms, bodies, medication, everything. What should we do not to catch another disease and not to infect someone with HIV? How can a pregnancy be prevented? About the Pap test [preventive cervix cancer test], when should I do it? (A15) 
These reports express adolescents' desire to know more about the extent of the questions about sexuality during adolescence and show that one of the ways to answer their questions is "to talk about [...] what we like". Based on this, guidance should begin with their needs and experiences, not the other way around, which is what has frequently happened in the family, school and health services.

Thus, an adequate perspective when approaching the theme of sexuality with adolescents must be centered on the understanding that it is not restricted to the explanation about organic sexual maturation, as it encompasses the understanding of its relational contexts. ${ }^{4,11}$ This requires nurses and other health professionals to value adolescents' knowledge and to establish a relationship of exchange of knowledge..$^{4,26}$

Thus, far from being centered on the transmission of information and behavioral effects, health education aimed at adolescents must be founded on a critical, participatory and emancipatory model, focused on the interaction and development of group awareness. ${ }^{27}$ This type of health education is strongly influenced by Paulo Freire's dialogical model, which begins with the subject and their reality and is centered on the development of their critical awareness. ${ }^{28}$

For nurses, this approach implies the adoption and adaptation of language, so that it is easily understood in the communication context of individuals. Additionally, it includes a relationship between these individuals and the educator, taking on an attitude of sharing, empathy, kindness, authenticity and humbleness, thus enabling trust to be achieved. ${ }^{4,27}$

Information was exclusively directed towards the biological and preventive question and, even then, it was insufficient and did not impact on the construction of adolescents' knowledge, as they reported that they were unprepared to experience their sexuality.

I'd have to know a little more, because it's good to know a bit of everything, not only half of it, because we can forget this half when we decide to do it [sexual intercourse] and get anxious. There are things I need to learn. (A13)

I don't know anything, I'm not prepared. They're not giving us enough guidance. Teens have to know everything. (A8)

I don't know many things, I'm not prepared. I never really looked into these things. We hear some things around and we think this is enough. I need more information. It's a big commitment, it's serious, we must be well instructed. (A7)

This (lack of) knowledge indicated by adolescents probably occurs because isolated information about prevention does not make sense in their lives, as it results from a de-contextualization of technical-scientific information that ends up not having an impact on their understanding and probably on the experiences of adolescents in this field.

The choice of use of preventive and contraceptive methods cannot be understood as something merely rational, because it is culturally and socially constructed above all. This is because their use is associated with several questions, such as: how individuals access information and how they interpret it, how they access the methods themselves, how gender relationships define the use of such methods and how the practices experienced by others influence them, among other things. ${ }^{4,29}$

Therefore, do health and education professionals feel prepared and want to discuss the senses and meanings of sexuality involved in the socio-cultural context of these individuals, aiming to establish ways for communication? Apparently not and, as a result, several factors were found to interfere with the possibility of helping adolescents to have a healthy sexual experience. The lack of an approach to this theme during the qualification of health professionals is one such factor, thus leading to successive obstacles that prevent them from dealing with sexuality in their health care practice.

\section{CONCLUSION}

Adolescents mainly constructed their knowledge from the relationships with friends and older family members and access to media sources. In contrast, discussing sexuality with parents and grandparents is a taboo yet. However, approaching this theme became at times more flexible, although aiming to discuss preventive issues exclusively. Some adolescents who were orphans missed their mother or father as someone who could advise them and answer their questions about this theme.

Schools and health services were found to be spaces for sharing information about the biological aspects of sexuality. Considering the fact that both families and schools/health services lacked information about sexuality, lack of preparation and knowledge about sexual experiences was reported. In this sense, adolescents mentioned that guidance must start from their own needs and experiences.

It is understood that the approach to sexuality needs to be a commitment of equal responsibility among all health professionals, as this theme includes a variety of disciplines. Additionally, the inclusion of nurses in health education practices with adolescents stands out, especially due to the possibility of performing educational actions that can encourage individuals to be emancipated. In this sense, educational actions need to primarily prevent AIDS from being the center of life of these adolescents, thus enabling different experiences such as sexuality to be valued.

Aiming to achieve a dialogical problematizing health education, the nurses' need to rethink their approach to educational practices is confirmed, so that the essential horizontality is allowed to construct effective health care projects. Additionally, the following question was raised: How can other educational practices be included in the routine of health services, without being based on silence, passivity and transmission of information to adolescents? There certainly are no ready-made answers or rules of behavior, although critical health education can help this construction. 
Nurses supporting an emancipatory education should consider the fact that individuals who are the focus of educational practices have their own perspective of the world, based on their histories of life and socio-cultural context. Thus, health education begins and ends in the community, i.e. where these adolescents are, beyond the reach of health services.

Likewise, health services do not frequently make investments to receive and incorporate peers and family members in health education actions, a gap that certainly interferes with the ways they deal with sexuality. In light of this, nurses are urged to develop their interaction with these individuals.

Other studies on sexuality should be performed with family members or caregivers of adolescents living with HIV/AIDS, thus enabling a better understanding of how families perceive and deal with this theme with the population in question. Finally, the limitations to the present study are associated with the difficult approach to this theme, considered to be delicate, as discussing it can lead to feelings of shame and embarrassment, among others.

\section{REFERENCES}

1. Soares GB, Garbin CAS, Rovida TAS, Garbin AJI. Quality of life of people living with HIV/AIDS treated by the specialized service in VitóriaES, Brazil. Ciênc Saúde Coletiva [Internet]. 2015 Apr; [cited 2017 Feb 19]; 20(4):1075-84. Available from: http://dx.doi.org/10.1590/141381232015204.00522014

2. Ministério da Saúde (BR). Boletim Epidemiológico Aids e DST: $27^{\text {a }}$

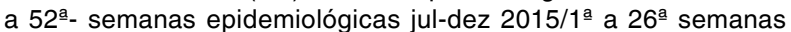
epidemiológicas Ano V nำ1. Brasília (DF): Ministério da Saúde; 2016.

3. Baheiraei A, Khoori E, Foroushani AR, Ahmadi F, Ybarra ML. What sources do adolescents turn to for information about their health concerns? Int J Adolesc Med Health [Internet]. 2014; [cited 2017 Feb 19]; 26(1):61-8. Available from: https://www.ncbi.nlm.nih.gov/ pubmed/23625280

4. Sehnem GD, Brondani JP, Kantorski KJC, Silva SC, Ressel LB, Pedro ENR. Health in adolescence with HIV / AIDS: paths for a post-2015 schedule. Rev Gaúcha Enferm [Internet]. 2015; [cited 2016 Dec 19]; 36(no.spe):39-46. Available from: http://dx.doi.org/10.1590/19831447.2015.esp.57385

5. Fair C, Wiener L, Zadeh S, Albright J, Mellins CA, Mancilla M, et al. Reproductive health decision-making in perinatally HIV-infected adolescents and young adults. Matern Child Health J [Internet]. 2013 Jul; [cited 2017 Feb 11]; 17(5):797-808. Available from: https://www. ncbi.nlm.nih.gov/pmc/articles/PMC3687209/

6. Madiba S, Mokgatle M. Perceptions and Experiences about SelfDisclosure of HIV Status among Adolescents with Perinatal Acquired HIV in Poor-Resourced Communities in South Africa. AIDS Res Treat [Internet]. 2016 Sep; [cited 2017 Feb 11]; 2016:2607249. Available from: https://www.ncbi.nlm.nih.gov/pmc/articles/PMC5031873/

7. Ferraz D, Paiva V. Sex, human rights and AIDS: an analysis of new technologies for HIV prevention in the Brazilian context. Rev Bras Epidemiol [Internet]. 2015 Sep; [cited 2017 Feb 11]; 18(Suppl 1):89103. Available from: http://www.scielo.br/scielo.php?script=sci_ arttext\&pid=S1415-790X2015000500089\&Ing=en\&nrm=iso\&tlng=en

8. Heilborn ML. Por uma agenda positiva dos direitos sexuais da adolescência. Psicol Clin [Internet]. 2012; [cited 2017 Feb 10]; 24(1):57-68. Available from: https://dx.doi.org/10.1590/S010356652012000100005

9. Baheiraei A, Khoori E, Ahmadi F, Rahimi Foroushani A, Ghofranipour F . Health concerns of Iranian adolescents: protocol for a mixed methods study. Iran Red Crescent Med J [Internet]. 2014 Jun; [cited 2017 Mar 10]; 16(6):e6715. Available from: https://www.ncbi.nlm.nih.gov/pmc/ articles/PMC4102994

10. Minayo MCS. O desafio do conhecimento: pesquisa qualitativa em saúde. 14ª ed. São Paulo: Hucitec; 2014

11. Ministério da Saúde (BR). Secretária de Atenção à Saúde. Orientações básicas de atenção integral à saúde de adolescentes nas escolas e unidades básicas de saúde. Brasília: Ministério da Saúde; 2013.

12. Morgan EM, Korobov N. Interpersonal identity formation in conversations with close friends about dating relationships. J Adolesc [Internet].2012 Dec; [cited 2017 Feb 19]; 35(6):1471-83. Available from: https://www.ncbi.nlm.nih.gov/pubmed/21986354

13. Davis AN, Gahagan JC, George C. "Everyone just keeps their eyes closed and their fingers crossed": sexual health communication among black parents and children in Nova Scotia, Canada. Int J Equity Health [Internet]. 2013 Jul; [cited 2017 Feb 19]; 12:55. Available from: https:// www.ncbi.nlm.nih.gov/pmc/articles/PMC3765904/

14. Macedo SRH, Miranda FAN, Pessoa Júnior JM, Nóbrega VKM Adolescência e sexualidade: scripts sexuais a partir das representações sociais. Rev Bras Enferm. [Internet]. 2013 Feb; [cited 2017 Feb 19]; 66(1):103-9. Available from: http://dx.doi.org/10.1590/S003471672013000100016

15. Widman L, Choukas-Bradley S, Helms SW, Prinstein MJ. Adolescent Susceptibility to Peer Influence in Sexual Situations. J Adolesc Health [Internet]. 2016 Mar; [cited 2017 Feb 19]; 58(3):323-9. Available from: https://www.ncbi.nlm.nih.gov/pmc/articles/PMC4766019/

16. Tomé G, Matos M, Simões C, Diniz JA, Camacho I. How can peer group influence the behavior of adolescents: explanatory model. Glob J Health Sci [Internet]. 2012; [cited 2017 Jun 14]; 4(2):26-35. Available from: https://www.ncbi.nlm.nih.gov/pmc/articles/PMC4777050/

17. Sehnem GD, Pedro ENR, Budó MLD, Silva FM, Ressel LB. A construção da sexualidade de estudantes de enfermagem e suas percepções acerca da temática. Ciênc Enferm [Internet]. 2014 Apr; [cited 2017 Feb 19];20(1):111-21. Available from: http://dx.doi.org/10.4067/S071795532014000100010

18. Ferreira AGN, Vieira NFC, Trasferetti A, Galvão MTG, Gubert FA Pinheiro PNC. Talking with adolescents from religious groups about HIV: challenges for nursing. Texto Contexto Enferm [Internet] 2013 Oct/Dec; [cited 2017 Feb 19]; 22(4):952-60. Available from: http://www.scielo.br/scielo.php?script=sci_arttext\&pid=S0104$07072013000400011 \&$ Ing=en

19. Shams M, Parhizkar S, Mousavizadeh A, Majdpour M. Mothers views about sexual health education for their adolescent daughters: a qualitative study. Reprod Health [Internet]. 2017 Feb; [cited 2017 Mar 1]; 14:24. Available from: https://www.ncbi.nlm.nih.gov/pmc/articles/ PMC5301399/

20. Cedaro JJ, Vilas Boas LMS, Martins RM. Adolescência e sexualidade um estudo exploratório em uma escola de Porto Velho - RO. Psicol Cienc Prof [Internet]. 2012; [cited 2017 Mar 10]; 32(2):320-39. Available from: http://www.scielo.br/scielo.php?script=sci_arttext\&p $\mathrm{d}=$ S1414-98932012000200005

21. Kennedy EC, Bulu S, Harris J, Humphreys D, Malverus J, Gray NJ. "These issues aren't talked about at home": a qualitative study of the sexual and reproductive health information preferences of adolescents in Vanuatu. BMC Public Health [Internet]. 2014 Jul; [cited 2016 Dec 19]; 14:770. Available from: https://www.ncbi.nlm.nih.gov/pmc/articles/ PMC4133612/

22. Salomão R, Silva MAI, Cano MAT. Sexualidade do adolescente na percepção dos pais, sob a perspectiva de Foucault. Rev Eletr Enferm [Internet]. $2013 \mathrm{Jul} / \mathrm{Sep}$; [cited 2017 Mar 10]; 15(3):609-18. Available from: https://www.fen.ufg.br/fen_revista/v15/n3/pdf/v15n3a02.pdf

23. Grajales Atehortúa IC, Cardona Arango D. Actitudes de los adolescentes escolarizados frente a la salud sexual y reproductiva. Medellín (Colombia). Invest Educ Enferm. [Internet]. 2012 Mar; [cited 2017 Mar 10]; 30(1):77-85. Available from: http://www.redalyc.org/ articulo.oa?id=105224287007 
24. Sfair SC, Bittar M, Lopes RE. Educação sexual para adolescentes e jovens: mapeando proposições oficiais. Saúde Soc [Internet]. 2015 Jun; [cited 2017 Mar 6]; 24(2):620-32. Available from: http://www.scielo.br/ pdf/sausoc/v24n2/0104-1290-sausoc-24-02-00620.pdf

25. Silva SC, Ressel LB, Pedro ENR, Alves CN, Stumm K, Wilhelm LA. Perceptions of adolescent women regarding gender differences: a descriptive study. Online Braz J Nurs [Internet]. 2014 Jun; [cited 2017 Feb 28]; 13(2):259-67. Available from: http://www.objnursing.uff.br/index. php/nursing/article/view/4236

26. Sousa ZAA, Silva JG, Ferreira MA. Saberes e práticas de adolescentes sobre saúde: implicações para o estilo de vida e cuidado de si. Esc Anna Nery [Internet]. 2014 Jul/Sep; [cited 2017 Mar 6]; 18(3):400-6. Available from: http://www.scielo.br/pdf/ean/v18n3/1414-8145-ean-18-03-0400. pdf
27. Feio A, Oliveira CC. Confluências e divergências conceituais em educação em saúde. Saúde Soc [Internet]. 2015; [cited 2017 Jun 14]; 24(2):703-15. Available from: http://www.scielo.br/pdf/sausoc/ v24n2/0104-1290-sausoc-24-02-00703.pdf

28. Freire P. Pedagogia do oprimido. $50^{\mathrm{a}}$ ed. Rio de Janeiro: Paz e Terra; 2011.

29. Nelson LE, Morrison-Beedy D, Kearney MH, Dozier A. Always, never, or sometimes: examining variation in condom-use decision making among Black adolescent mothers. Res Nurs Health [Internet]. 2011 Aug; [cited 2017 Feb 21]; 34(4):270-81. Available from: https://www.ncbi.nlm.nih. gov/pmc/articles/PMC3412046/ 